Summary

Viktoriya Kravets. Administrative and legal characteristics of the primary historical stages of origin, formation and development of medical care.

This article is devoted to the doctrinal study of the genesis of the origin, formation and development of health care, resulting in a study of traditions, customs that have been passed down from generation to generation.

The periodization of the history of medicine in Ukraine is formed, which is expediently presented in the form of its systematization and to formulate its stages, namely: the initial stage (600 million years ago to the XII-VI millennium BC); stage of Kievan Rus (IX century to XIII century); Polish-Lithuanian stage (including Cossack statehood) (XIV to the first half of the XVII century); The imperial stage (includes the reigns of Peter I, Catherine II and Nicholas II) (XVIII - to the XIX century), the Soviet stage (XX century), the stage of Ukrainian independence (second half of the XX century), the stage of Modern Ukraine (early XXI century - to this day).

Also, it was concluded that the main features of the "Initial stage" of the formation and development of medical care are: 1) begins to be used in the provision of medical care herbal medicines; 2 ) there is a use of drugs that determine the mechanism of action on the human body, namely: narcotic effects, stimulant effects, tonic effects, etc.; 3) the use of magic in the provision of medical care, which arose as a result of empirical research. Accordingly, the main features of the "stage of Kievan Rus" formation and development of medical care are: 1) the development of pagan treatment; 2) active development and implementation of the monastic direction of treatment; 3) the use of folk medicine in the treatment of patients; 4) dissemination of knowledge and practical skills by monks of the Kiev-Pechersk Lavra to neighboring lands; 5) the introduction of monastic hospitals, where monks were so humane to the sick to the point of self-sacrifice; 6) monasteries became centers of culture and education; 7) there was a separation of such areas of medical care as surgical, orthopedic and therapeutic, etc.

Key words: service, medical service, genesis, formation, development.

DOI: $10.36695 / 2219-5521.4 .2020 .36$

УДК 342.9

\title{
М.В. ПЛЕСКАЧ
}

Марія Василівна Плескач, аспірантка Київського національного університету імені Тараса Шевченка*

ORCID: 0000-0003-3296-5475

\section{СУТНІСТЬ ПОНЯТТЯ ТА ОСНОВНІ ЕЛЕМЕНТИ МЕХАНІЗМУ АДМІНІСТРАТИВНО- ПРАВОВОГО ЗАБЕЗПЕЧЕННЯ КІБЕРНЕТИЧНОЇ БЕЗПЕКИ ЛЮДИНИ}

Постановка проблеми. Створення належних умов для використання людиною інформаційно-комунікаційних та цифрових технологій, ефективного захисту ії прав, інтересів та свобод у кібернетичному просторі є складним завданням без застосування дієвого механізму адміністративно-правового забезпечення. Поточні показники України у таких міжнародних рейтингах, як-от: Глобальному індексі кібербезпеки (Global Cybersecurity Index); Національному індексі кібербезпеки (National Cybersecurity Index); Індексі розвитку інформаційно-комунікаційних технологій (ICT Development Index) свідчать, що попри зроблені важливі кроки у напрямі вдосконалення механізму адміністративно-правового забезпечення кібербезпеки, нині він залишається не надто ефективним порівняно $з$ механізмами таких розвинених країн, як Великобританія, США, Франція, Литва, Естонія, Сінгапур, Норвегія та Канада. 3 огляду на це існує потреба в дослідженні можливих напрямів удосконалення національного механізму адміністративно-правового забезпечення кібернетичної безпеки, передусім людини.

Аналіз останніх досліджень і публікацій. Різні аспекти правового забезпечення кібернетичної безпеки людини досліджуються вітчизняними та зарубіжними вченими-правознавцями. Наприклад, вказана сфера $є$ предметом наукових пошуків таких зарубіжних вчених: Рольфа Х. Вебера (Rolf H.Weber), праці якого висвітлюють нові парадигми безпеки та правового регулювання, що спричинені невпинним проникненням технологій у повсякденне життя людини룰 Рональда Дж. Дейберта (Ronald J. Deibert), який у своїх дослідженнях акцентує увагу на важливості надання пріоритету людині у питаннях забезпечення кібернетичної безпеки. Основні елементи орієнтованого на людину підходу до кібербезпеки окреслені та протиставлені у його працях переважаючим тенденціям щодо практик, орієнтованих на національну (державну) безпеку2.

Дослідження українських науковців також присвячені вивченню проблем правового забезпечення кібернетичної безпеки людини. Так, у наукових роботах О.А. Заярного висвітлюються методологічні проблеми запобігання адміністративним інформаційним правопорушенням (що є важливим інструментом публічного адміністрування) у цій сфері 3 ; О.О. Золотар, яка висвітлює правові основи інформаційної безпеки людини ${ }^{4}$; В.А. Омельчука, який робить акцент на правових аспектах протидії булінгу (як одного із аспектів кібербезпеки, а відтак національної безпеки $)^{5}$; А.В. Тарасюка, який розкриває методологічні підходи до вивчення проблеми безпеки людини в кіберпросторіб; О.В. Олійника, який досліджує вказану проблематику,

(C) М.В. Плескач, 2020

* Mariia Pleskach, Postgraduate student of Taras Shevchenko National University of Kyiv 
але у контексті зарубіжного досвіду7; Я.Я. Мельника, який розглядає феномен «безпеки» у приватноправових відносинах, зокрема його місце в цивільних процесуальних категоріях «інтерес», «свобода», «право», «обов’язок» та «відповідальність», і які є найбільш дотичними до людини ${ }^{8}$.

Аналіз останніх досліджень і публікацій дає змогу стверджувати про те, що нині науковці надають перевагу вивченню проблематики, орієнтованої на правове забезпечення національної (державної) кібернетичної безпеки, не приділяючи значної уваги проблемам адміністративно-правового забезпечення кібернетичної безпеки людини, а відтак і розробці відповідного правового механізму.

Формулювання мети статті. Метою цього дослідження є розкриття змісту поняття «механізм адміністративно-правового забезпечення кібернетичної безпеки людини», його ознак, елементів (структури), а також виокремлення деяких напрямів удосконалення цього механізму із наданням відповідних практичних рекомендацій.

Виклад основного матеріалу. Для того, аби розкрити поняття «механізм адміністративно-правового забезпечення кібернетичної безпеки людини», його основні ознаки, а також основні елементи (структуру), застосовуючи метод аналізу, розглянемо первинні базові поняття, зокрема «механізм», яке першопочатково виникло в обігу окремої науки - механіки. Згодом розвиток наукового знання призвів до того, що це поняття було запозичено іншими науками i, зрештою, поширилось на юридичні знання. Так, під механізмом у найбільш загальному значенні розуміють певний спосіб зробити щось у межах певної системи ${ }^{9}$. Використання поняття «механізм» у науковому обігу виконує важливу методологічну функцію, адже організовує знання, сприяє кращому розумінню дійсності, відтворює явища в їх істотних ознаках ${ }^{10}$.

У правовій доктрині нині використовуються такі юридичні поняття, як-от: «механізм правового забезпечення», «механізм правового регулювання», «механізм адміністративно-правового забезпечення» тощо. Із аналізу наукових праць випливає, що нерідко «механізм правового забезпечення» та «механізм правового регулювання» ототожнюються. Наприклад, С.В. Діденко, розглядаючи поняття та елементи механізму адміністративно-правового забезпечення обігу та застосування зброї в Україні, зазначає, що у зв'язку з тим, що адміністративно-правове забезпечення обігу та застосування зброї полягає у виявленні й створенні адміністративних засад та інструментарію реалізації адміністративно-правових відносин у цій сфері, а також охороні та гарантуванні прав, свобод і законних інтересів суб'єктів цих відносин на основі правових норм, механізм адміністративно-правового забезпечення потрібно розглядати через призму правового регулювання та брати його за основу під час формування відповідних висновків ${ }^{11}$.

У свою чергу I.О. Личенко поняття адміністративно-правового забезпечення (у контексті екологічної безпеки в Україні) розуміс як сукупність адміністративно-правових гарантій і діяльнісних засобів 12 .

Вбачається, що подібне ототожнення призводить до надмірного звуження змісту поняття «правове забезпечення», а відтак і його механізму. Зазначимо, що між правовим забезпеченням та правовим регулюванням $є$ відмінності, які виражаються у змісті, обсязі та структурних елементах. Цю позицію можемо довести через такі аргументи: по-перше, правове регулювання - це передусім здійснюваний за допомогою права і всієї сукупності правових засобів юридичний вплив на суспільні відносини ${ }^{13}$, а правове забезпечення - це складна диференційована єдність багатьох складників (суб'єктів, цілей, результатів, дій та операцій, засобів та способів здійснення такого забезпечення), які не лише функціонально взаємодіють, а й органічно поєднані між собою за допомогою мережі структурних, вертикальних, горизонтальних, координаційних, субординаційних, просторових, часових тощо відносин ${ }^{14}$. Незважаючи на те, що ці два поняття об'єднують у собі і процес творення правових норм, і їх реалізацію за допомогою спеціальних юридичних засобів, все ж обсяг поняття «правове регулювання» не містить таких компонентів, як забезпечувальні заходи (політико-правові, матеріально-технічні, організаційно-управлінські, кадрові, технологічні тощо), на відміну від поняття «правове забезпечення» 14 ; по-друге, правове забезпечення та правове регулювання мають різні структурні елементи. Зокрема, на думку О.Ф. Скакун, до механізму правового регулювання входять такі елементи, обов'язкові на окремих його стадіях: принципи права, норми права, нетипові правові розпорядження (спеціалізовані норми права), об'єктивовані в нормативно-правових актах; правовідносини, суб'єктивні юридичні права i обов'язки в їх індивідуалізації (конкретизації); акти безпосередньої реалізації прав та обовязків; акти застосування норм права ${ }^{15}$.

У свою чергу, до елементної бази механізму правового забезпечення (у контексті адміністративного права) входять: об'єкт адміністративно-правового забезпечення; суб'єкти адміністративно-правового забезпечення; принципи права, норми права, правовідносини, їх зміст, види, структура та особливості реалізації; гарантії, заходи, засоби форми, принципи та методи правового забезпечення 16 .

Виходячи із цих позицій, екстраполюємо вказані висновки на характеристику механізму адміністративно-правового забезпечення кібернетичної безпеки людини. Предметом адміністративного права України $\epsilon$ суспільні відносини, які виникають між суб'єктами публічної адміністрації та приватними особами, а за змістом предмет адміністративного права складається з надання адміністративних послуг і здійснення виконавчо-розпорядчої діяльності (публічного управління) адміністрацією ${ }^{17}$, адміністративно-правовим забезпеченням у найбільш загальному розумінні можна вважати систему заходів, які здійснюються з певною метою публічною адміністрацією ${ }^{18}$.

Отже, механізмом адміністративно-правового забезпечення кібернетичної безпеки людини можна вважати узяту в єдності складну систему юридичних, організаційних, ідеологічних, технічних та інших заходів впливу, що здійснюється уповноваженими суб'єктами публічної адміністрації на суспільні відносини, які 
виникають під час використання кібернетичного простору, з метою їх упорядкування, а також для забезпечення охорони й захисту життєво важливих інтересів, прав та свобод людини в цій сфері.

Структура механізму адміністративно-правового забезпечення кібернетичної безпеки людини передусім залежить від того, що саме офіційно вважається кібернетичною безпекою в державі. Тобто широкий чи вузький підхід $є$ превалюючим у розумінні цього поняття.

У цьому дослідженні вважаємо за доцільне взяти за основу широкий підхід розуміння поняття «кібернетична безпека», яка нині відповідно до ст. 1 Закону України «Про основні засади забезпечення кібернетичної безпеки України» розглядається як захищеність життєво важливих інтересів людини і громадянина, суспільства та держави під час використання кіберпростору, за якої забезпечуються сталий розвиток інформаційного суспільства та цифрового комунікативного середовища, своєчасне виявлення, запобігання і нейтралізація реальних та потенційних загроз національній безпеці України у кіберпросторі.

Орієнтуючись на вищевказане визначення механізму адміністративно-правового забезпечення кібернетичної безпеки людини, до його основних елементів можна віднести: нормативні засади механізму адміністративно-правового забезпечення кібернетичної безпеки людини (принципи права, норми права); об’єкт адміністративно-правового забезпечення кібернетичної безпеки людини (правовідносини, їх зміст, види, структуру та особливості реалізації); суб'єктів адміністративно-правового забезпечення кібернетичної безпеки людини; засоби адміністративно-правового забезпечення кібернетичної безпеки людини.

Окресливши поняття, а також основні елементи механізму адміністративно-правового забезпечення кібернетичної безпеки людини, доцільно розглянути його нормативні засади як один із важливих його елементів. Нормативні засади механізму правового забезпечення кібернетичної безпеки людини містяться як у галузях публічного, так і у галузях приватного права, зокрема у конституційному, адміністративному, кримінальному, цивільному праві. Тому, зважаючи на подвійну природу предмета інформаційного права, на нашу думку, нормативні засади механізму правового забезпечення варто розглядати комплексно, але при цьому враховувати, що застосування того чи іншого нормативно-правового акта залежатиме від характеру правовідносин (приватні чи публічні), які потребують врегулювання, а також від того, які інтереси ним забезпечуються (колективні або індивідуальні).

Сфері кібернетичної безпеки як інституту інформаційного права також притаманна наявність як норм публічного права, так норм і приватного права. А специфіка предмета правового регулювання потребує суміщення кількох методів правового регулювання - як диспозитивного, так і імперативного. Норми як публічного, так і приватного матеріального права закріплюють, створюють, регулюють, охороняють, а також захищають відповідні права, свободи та інтереси людини у кібернетичному просторі. Загалом, не виокремлюючи публічну чи приватноправову складову, нормативні засади механізму правового забезпечення кібернетичної безпеки людини можна подати через: відповідну систему нормативно-правових актів; правових принципів; міжнародних та національних стандартів, що регулюють цю сферу.

Зазначимо, що правове регулювання сфери кібернетичної безпеки характеризується відсутністю чіткої структурованості, однак до основних нормативно-правових актів, що регулюють правовідносини, які виникають під час використання кібернетичного простору задля створення умов безпечного його використання, а також охорони, захисту життєвоважливих інтересів, прав і свобод людини, можна віднести:

1) чинні міжнародні договори, згода на обов'язковість яких надана Верховною Радою України, адже значна частина кіберпростору є де-факто міжнародною, і лише в окремих випадках його функціонування знаходиться під контролем і суверенітетом відповідної держави. Тому можна стверджувати, що значна частина відносин в кіберпросторі може бути врегульована засобами міжнародного права, до яких варто віднести зокрема: Загальну декларацію прав людини; Конвенцію про кіберзлочинність 2001 р.; Конвенцію про захист осіб у зв'язку з автоматизованою обробкою персональних даних та інші. Окремої уваги заслуговує Загальний регламент про захист даних (General Data Protection Regulation, GDPR; Regulation (EU) 2016/679). Загальний регламент про захист даних хоча і не може вважатися повноцінним джерелом права в Україні, однак положення цього нормативно-правового акта поширюються на тих суб'єктів, які здійснюють свою діяльність, зокрема і у всесвітній мережі Інтернет, на території Європейського Союзу або прямо чи опосередковано мають доступ до персональних даних осіб, які знаходяться на території Європейського Союзу;

2) нормативно-правові акти України, зокрема: Конституцію України; Кримінальний кодекс України; Кодекс України про адміністративні правопорушення; Цивільний кодекс України; галузеві нормативно-правові акти України (закони України), які містять норми, що регулюють правовідносини, що виникають під час використання кіберпростору, і спрямовані на охорону й захист прав, свобод, інтересів людини у цій сфері: Закон України «Про основні засади забезпечення кібербезпеки України» від 5 жовтня 2017 р. 3a № 2163-VIII19; Закон України «Про захист персональних даних»20 та інші.

Вважаємо, що чинний Закон України «Про основні засади забезпечення кібербезпеки України» не вирішує наявних проблем галузі, більшість його норм є декларативними, тому необхідно або здійснити фундаментальну роботу з розробки та прийняття ефективного Закону України «Про кібернетичну безпеку», або внести низку змін до Закону України «Про основні засади забезпечення кібербезпеки України», а саме: удосконалити поняттєво-категоріальний апарат, зокрема дати належне визначення поняттю «кібербезпека». Так, iї варто визначати як сукупність організаційних, правових, технічних та освітніх заходів, спрямованих на безперервне функціонування кіберпростору, мінімізацію ризиків у його функціонуванні до прийнятного мінімуму, з метою охорони та захисту життєво важливих прав, свобод, інтересів людини, суспільства і дер- 
жави; конкретизувати об’єкти кібернетичної безпеки, тобто не тільки вказати, що це конституційні права i свободи людини і громадянина, а конкретизувати, які саме. Така конкретизація сприяла б чіткому розмежуванню функцій суб'єктів забезпечення кібернетичної безпеки; визначила принципи розмежування публічного (держава, суспільство) та приватного (людина) інтересів у кібернетичному просторі, 3 метою усунення проблеми повного або часткового неспівпадіння інтересів різних рівнів (людина, суспільство, держава). Так, до прикладу, інтересом державних силових та розвідувальних структур може бути моніторинг, негласне спостереження, відслідковування за ії громадянами і суспільством для забезпечення громадського порядку, тому для держави певною мірою є сприятливою ситуація незахищеності протоколів Інтернету для збору даних про окремих осіб. У свою чергу, людина заінтересована у тому, щоб їі права, у тому числі під час використання кібернетичного простору, не були порушені з боку держави, тому варто встановити мінімальні норми захисту та забезпечення інформаційної та кібернетичної безпеки не лише для об'єктів критичної інфраструктури, а й для усіх суб'єктів незалежно від форм власності, які є дотичними до персональних даних людини, чи діяльність яких може впливати на рівень кібербезпеки людини; забезпечити на практиці належне функціонування системи аудиту інформаційної безпеки; періодичного проведення огляду національної системи кібербезпеки, розроблення індикаторів стану кібербезпеки як того вимагає Закон України «Про основні засади забезпечення кібербезпеки України». У ч. 3 ст. 15 цього Закону України визначено, що діяльність основних суб'єктів національної кібербезпеки на предмет ефективності системи забезпечення кібербезпеки держави підлягає незалежному щорічному аудиту, за результатами якого складається звіт. Визначено, що основні суб' єкти національної кібербезпеки надають один раз на рік звіти про стан виконання ними заходів з питань забезпечення кібербезпеки. Нині в Україні відсутні офіційно оприлюднені звіти про стан забезпечення кібербезпеки в Україні, що не дає можливості скласти уявлення про дійсний стан речей у цій галузі, а також зрозуміти, наскільки є ефективним у своїй роботі той чи інший суб'єкт. Також потребує суттєвих доопрацювань і наближення до Загального регламенту про захист даних (General Data Protection Regulation, GDPR; Regulation (EU) 2016/679) чинний Закон України «Про захист персональних» даних, зокрема цей Закон потребує доповнення нормою, яка встановлює обов'язок повідомлення про випадки витоку даних, зобов'язує суб'єкта, у якого стався такий інцидент, повідомити в чітко встановлений строк про такий витік уповноважений орган держави, своїх клієнтів та інші сторони, зобов'язує вжити заходів щодо усунення заподіяної шкоди, а також встановлює відповідальність для винних осіб у разі, коли недостатній нагляд чи контроль, що мав здійснюватися особою, яка відповідальна за захист персональних даних, спричинив можливість такого витоку даних. Ця норма є особливо актуальною, зважаючи на невпинно зростаючу кількість випадків несанкціонованого доступу до баз даних в Україні, що містять інформацію про користувачів, і випадки використання цих даних проти волі людини;

3) міжнародні стандарти, стандарти Свропейського Союзу та НАТО у сфері забезпечення кібернетичної безпеки. Закон України «Про основні засади забезпечення кібербезпеки України» закріплює, що функціонування національної системи кібербезпеки має забезпечуватися із дотриманням міжнародних стандартів. Однак наявність цих положень не спричинила активізації системної розробки національних стандартів у сфері кібербезпеки.

В Україні досі не вирішено одну із основних проблем нормативно-технічного та нормативно-правового забезпечення суб'єктів кібербезпеки, а саме не врегульовано невідповідність стану й розвитку в Україні національної системи стандартизації у сфері кібербезпеки та кіберзахисту потребам забезпечення національної, інформаційної та кібернетичної безпеки, сталого розвитку цифрової економіки й суспільства, міжнародним зобов'язанням і вимогам національного законодавства. Неповнота, нечіткість, неузгодженість національної системи стандартизації у сфері кібербезпеки з міжнародними системами стандартизації та неврахування кращого міжнародного досвіду стримують іiі розвиток, негативно впливають на механізм забезпечення кібернетичної безпеки людини;

4) нормативно-правові акти Президента України, що регулюють питання забезпечення кібернетичної безпеки;

5) нормативно-правові акти Кабінету Міністрів України у сфері забезпечення кібернетичної безпеки;

6) нормативні джерела, які регулюють порядок взаємодії суб'єктів системи забезпечення кібернетичної безпеки за окремими напрямами діяльності в цій сфері;

7) нормативно-правові акти інших суб'єктів, відповідальних за забезпечення кібернетичної безпеки, зокрема Національної комісії, що здійснює державне регулювання у сфері зв'язку та інформатизації; Державної служби спеціального зв'язку та захисту інформації України (Держспецзв'язку);

8) локальні нормативні акти - документи, що містять норми права, які розробляються приватними суб'єктами;

9) принципи міжнародного публічного права, які регулюють правовідносини, що виникають під час використання кіберпростору.

Як зазначає О.А. Заярний, одним із напрямів удосконалення способів захисту інформаційних прав людини в умовах застосування штучного інтелекту (один із аспектів кібернетичної безпеки людини) є впровадження у практичну діяльність етичного напряму, в основу якого включаються акти м'якого права - етичні норми та принципи, які містять адресовані розробникам або постачальникам вимоги щодо забезпечення дотримання інформаційних прав фізичної особи, заклики до недискримінації за ознаками застосування технологій штучного інтелекту чи відмови від їх застосування ${ }^{21}$. 
Важливим елементом механізму адміністративно-правового забезпечення кібернетичної безпеки людини є об 'єкт такого забезпечення. Об'єктом адміністративно-правового забезпечення кібернетичної безпеки людини є ті суспільні відносини, що виникають під час використання кібернетичного простору людиною і які урегульовуються нормами адміністративного права. Правовідносини, що виникають у кібернетичному просторі характеризуються такими ознаками: 1) обмін інформації відбувається в електронній цифровій формі; 2) віддаленість суб'єктів цих відносин у просторі; 3) наявність суб'єктів, які не ініціювали ці відносини, проте мали організаційно-технічну можливість здійснити вплив на них; 4) використання програмного забезпечення, технічних стандартів і протоколів; 5) схильність цих відносин до саморегуляції; 6) технологічна складність кіберпростору; 7) поширені можливості порушення інформаційних прав суб'єктів цих відносин 22.

Система (організованість) правовідносин розкривається через їх структуру. Структура правовідносин - це основні елементи правовідносин і доцільний спосіб зв'язку між ними на підставі суб'єктивних юридичних прав, обов'язків, повноважень і відповідальності з приводу соціального блага або забезпечення інтересів 15 . Таким чином, до структури адміністративно-правових відносин у сфері забезпечення кібернетичної безпеки людини входять: суб'єкти, об'єкти, зміст, а також юридичні факти.

Суб 'єктів публічної адміністрації, відповідальних за забезпечення кібернетичної безпеки, варто розподілити на такі основні групи (залежно від форми публічної влади - державної чи муніципальної).

До першої групи належать органи виконавчої влади (як державної влади). Відповідно до п. 1 ч. 4 ст. 5 Закону України «Про основні засади забезпечення кібернетичної безпеки» до органів виконавчої влади, які $\epsilon$ відповідальними за забезпечення кібернетичної безпеки, належать міністерства та інші центральні органи виконавчої влади, а також місцеві адміністрації. Нині головним органом у системі центральних органів виконавчої влади, що забезпечує формування та реалізацію державної політики: у сферах цифровізації, цифрового розвитку тощо, є Міністерство цифрової трансформації України.

Органами державної влади, що здійснюють публічне адміністрування у сфері забезпечення кібернетичної безпеки людини і які, відповідно до ч. 2 ст. 8 Закону України «Про основні засади забезпечення кібербезпеки України» утворюють національну систему кібербезпеки є:

1) Національна поліція України, яка є відповідальною за забезпечення захисту прав і свобод людини і громадянина, інтересів суспільства і держави від злочинних посягань у кіберпросторі; здійснює заходи із запобігання, виявлення, припинення та розкриття кіберзлочинів, підвищення поінформованості громадян про безпеку в кіберпросторі. Нині в Україні як структурний підрозділ Національної поліції України функціонує Департамент кіберполіції Національної поліції України, завданням якого має бути визначення, розробка та реалізація комплексу заходів, спрямованих на попередження й протидію кримінальним правопорушенням у кібернетичному просторі. Однак, на жаль, досі не затверджено відповідне Положення про Департамент кіберполіції Національної поліції України, яке врегулювало б правовий статус цього структурного підрозділу та належним чином легітимізувало його діяльність;

2) Державна служба спеціального зв'язку та захисту інформації України, яка серед іншого є відповідальною за забезпечення функціонування Державного центру кіберзахисту, урядової команди реагування на комп'ютерні надзвичайні події України CERT-UA. Зазначимо, що останній відповідальний також за забезпечення кібернетичної безпеки людини. У зв'язку з тим, що станом на 2020 р. досі не прийнято Закону України «Про критичну інфраструктуру та їі захист», у якому б було визначено чіткі критерії віднесення того чи іншого суб'єкта діяльності до об'єктів критичної інфраструктури, Державна служба спеціального зв'язку та захисту інформації України має необмежені повноваження щодо виставлення вимог, які стосуються кібернетичної безпеки для як для державних, так і недержавних суб'єктів, що може спричиняти перешкоди у їх діяльності;

3) Міністерство оборони України, Генеральний штаб Збройних Сил України;

4) розвідувальні органи України.

До органів державної влади, що здійснюють публічне адміністрування у сфері забезпечення кібернетичної безпеки людини, але формально не підпорядковані вищому чи центральним органам виконавчої влади належать: 1) Національний координаційний центр кібербезпеки як робочий орган Ради національної безпеки і оборони України, утворений відповідно до рішення Ради національної безпеки і оборони України від 27 січня 2016 р. «Про Стратегію кібербезпеки України», уведений в дію Указом Президента України від 15 березня 2016 р. № 96. Однак станом на 2020 р. немає жодного офіційного опублікованого національного Звіту про стан забезпечення кібербезпеки в Україні, що не дає усім заінтересованим суб'єктам: по-перше, розуміння поточної ситуації у цій галузі, по-друге, здійснити оцінку ефективності роботи Національного координаційного центру кібербезпеки. Такий стан речей негативно впливає на можливість оцінки перспектив розвитку сфери кібербезпеки. Також важливо, аби координація у сфері забезпечення кібернетичної безпеки відбувалась не лише між органами публічної адміністрації, а й із залученням приватних осіб. Так, для прикладу, у Естонії функціонує національна платформа для координації державного і приватного сектора у сфері забезпечення кібернетичної безпеки $\mathrm{X}-\mathrm{Road}^{23}$; 2) Служба безпеки України, на яку покладено завдання щодо здійснення запобігання, виявлення, припинення та розкриття злочинів проти миру і безпеки людства, які вчиняються у кіберпросторі; здійснення контррозвідувальних та оперативно-розшукових заходів, спрямованих на боротьбу з кібертероризмом та кібершпигунством; 3) Національний банк України у межах своєї компетенції визначає порядок, вимоги та заходи із забезпечення кіберзахисту та інформаційної безпеки у банківській системі України та для суб'єктів переказу коштів тощо. 
До другої групи основних суб 'єктів публічної адміністраиї̈, відповідальних за забезпечення кібернетичної безпеки людини, належать суб'єкти місцевого самоврядування. Органи місцевого самоврядування $є$ також відповідальними за забезпечення кібернетичної безпеки людини, оскільки вони становлять найбільший пласт суспільних відносин, пов'язаних із реалізацією їхньої компетенції в різних сферах забезпечення життєдіяльності людей. Крім цього, значущість захищеності життєво важливих інтересів людини та громадянина у сфері функціонування органів місцевого самоврядування буде лише зростати, що зумовлено передусім поступовою децентралізацією публічної влади 24.

До третьої групи належать суб'єкти делегованих повноважень, а саме: громадські об'єднання; інші суб'єкти під час здійснення делегованих законодавством виконавчих функцій. До них за Законом України «Про основні засади забезпечення кібернетичної безпеки України» входять: суб'єкти господарювання, громадяни України та об'єднання громадян, інші особи, які провадять діяльність та/або надають послуги, пов'язані з національними інформаційними ресурсами, інформаційними електронними послугами, здійсненням електронних правочинів, електронними комунікаціями, захистом інформації та кіберзахистом.

Нині можна констатувати, що обмеженість національної системи кібербезпеки на практиці лише органами публічної адміністрації без залучення громадськості та приватних осіб, які є фахівцями у сфері забезпечення кібернетичної безпеки, призводить до відсутності дійсного контролю за органами державної влади, різними зловживаннями, а також до зростання недовіри та збільшення протиріч між різними суб'єктами забезпечення кібернетичної безпеки. Зважаючи на те, що кібернетичний простір характеризується динамічністю та непередбачуваністю, суттєвою допомогою у запобіганні кіберінцидентам могло б стати залучення до співпраці приватних осіб, які спеціалізуються на пошуку та виправленні слабких місць у системах забезпечення кібернетичної безпеки. Дієвим способом щодо набуття впевненості у стійкості системи до нападів та кібератак $є$ тривале випробування й дослідження іiі фахівцями (хакерами).

Зважаючи на всі переваги від діяльності «білих та сірих» хакерів, нині в Україні досі не врегульовано їх правовий статус. Більш того, діяльність останніх кваліфікується як і діяльність «чорних» хакерів, і підпадає під дію розділу XVI Кримінального кодексу України за назвою «Кримінальні правопорушення у сфері використання електронно-обчислювальних машин (комп'ютерів), систем та комп'ютерних мереж і мереж електрозв'язку». Важливо, щоб нарешті діяльність добросовісних хакерів знайшла підтримку в державі через: розробку та прийняття нормативно-правового акта, який би: визначив перелік видів діяльності у сфері забезпечення кібернетичної безпеки, які не можуть вважатися протиправними, що вкрай необхідно для попередження кіберінцидентів; визначив правовий статус «білого» та «сірого» хакерів, їхні права, обов'язки; встановив порядок (процедуру) інформування компетентних суб'єктів щодо виявлених недоліків; строки повідомлення про уразливість певної системи тощо; розробку програм стимулювання фахівців у сфері забезпечення кібернетичної безпеки за виявлення і добросовісне повідомлення про вразливості кібернетичних систем із отриманням певної винагороди за таку діяльність.

Об'єкти правовідносин у сфері адміністративно-правового забезпечення кібернетичної безпеки людини можна поділити на:

1) нематеріальні, до яких належать права та свободи людини у кібернетичному просторі (публічні суб' Єктивні права): право людини на захист персональних даних під час використання кіберпростору; право людини на захист від агресивних маркетингових технологій у кіберпросторі тощо;

2) матеріальні, до яких входять програмні продукти, технології, програмне забезпечення; телекомунікаційні мережі, технічне обладнання тощо. Варто додати, що сам кіберпростір не є об’єктом правовідносин, адже він цілком нікому не може належати;

3) дії суб’єктів правовідносин у сфері адміністративно-правового забезпечення кібернетичної безпеки людини, у яких суб'єкт чи об'єкт публічного управління має право вимагати від зобов'язаної сторони виконання певних дій. Наприклад, право Уповноваженого з прав людини за підсумками перевірки, розгляду звернення видавати обов'язкові для виконання вимоги (приписи) про запобігання або усунення порушень законодавства про захист персональних даних, у тому числі ті, які було вчинено у кібернетичному просторі.

Ще одним елементом структури правовідносин у сфері адміністративно-правового забезпечення кібернетичної безпеки людини є зміст таких правовідносин. Зміст правовідносин у сфері адміністративно-правового забезпечення кібернетичної безпеки становлять суб'єктивні публічні права (публічної правоможності) та юридичні обов'язки суб'єктів адміністративного права, відповідальних за забезпечення кібернетичної безпеки людини, коли кожному суб'єктивному праву одного суб'єкта адміністративно-правових відносин відповідає (кореспондується) юридичний обов'язок іншого суб'єкта, і навпаки. За ступенем можливості реалізації права людини можуть поділятися на абсолютні й відносні25.

Абсолютними є такі права, реалізація яких залежить від волевиявлення людини, зокрема, це може бути право на отримання освітніх послуг шляхом використання кіберпростору; право вимагати відшкодування шкоди, завданої незаконними діями чи бездіяльністю суб'єктами публічної адміністрації, відповідальними за забезпечення кібернетичної безпеки тощо.

Відносні права в кіберпросторі - це такі, реалізація яких залежить не лише від волевиявлення людини, а й від наявності фактичних можливостей для їх реалізації. Зокрема, кожна людина має право на доступ до Інтернету, однак не у всіх регіонах України є можливість повноцінно реалізувати це право, передусім у зв'язку із недостатньою технічною оснащеністю. 
Плескач М.В. Сутність поняття та основні елементи механізму адміністративно-правового забезпечення...

Обов'язком же у цих правовідносинах буде виступати зобов'язання інших приватних осіб (людей), а також суб'єктів публічної адміністрації не перешкоджати людині у реалізації ії прав у кіберпросторі, крім випадків, передбачених законом, з метою запобігання кримінальним правопорушенням чи встановлення фактичних обставин у кримінальних справах, якщо іншими способами одержати інформацію неможливо, i лише на підставі рішення суду. Так само як і права, обов'язки людини у кіберпросторі можна поділити на абсолютні та відносні.

Абсолютні обов'язки людини у кіберпросторі - це обов'язки, виконання яких зумовлене правовим режимом (об'єктивною реальністю), тобто вимоги дотримання яких встановлено нормами чинного законодавства. Це може бути обов'язок не вчиняти правопорушень під час використання кіберпростору, відповідальність за які передбачена чинним законодавством.

Відносні обов'язки людини у кіберпросторі - це ті, які або залежать від волевиявлення людини (сприяння суб'єктам кібернетичної безпеки); або від певних життєвих обставин (в умовах існування загроз національній безпеці у кіберпросторі бути обмеженим у використанні певних електронних ресурсів, пов'язаних iз такою загрозою). Також можна виокремити ще таку групу обов'язків людини у кібернетичному просторі, як деліктні обов'язки, які виникають із деліктних правовідносин і покладаються на людину через їі протиправну поведінку та полягають в обов'язку людини зазнати відповідних обмежень прав і свобод як покарання за правопорушення, вчинене у кібернетичному просторі або з його використанням.

Залежно від спрямування діяльності суб'єктів публічної адміністрації, відповідальних за забезпечення кібернетичної безпеки, можна виокремити такі основні види правовідносин у сфері адміністративно-правового забезпечення кібернетичної безпеки людини: 1) правовідносини, що виникають за ініціативою приватної особи (вертикальні, побудовані за принципом «знизу догори») і розкриваються через сукупність суб'єктивних прав приватної особи та адміністративних обов'язків суб'єкта публічної адміністрації, відповідального за забезпечення кібернетичної безпеки; 2) правовідносини, що виникають за законною ініціативою суб'єкта публічної адміністрації відповідального за забезпечення кібернетичної безпеки (вертикальні, побудовані за принципом «згори донизу»). Розкриваються через сукупність адміністративних прав суб'єкта публічної адміністрації та юридичних обов'язків приватної особи; 3) правовідносини, у яких беруть участь два суб'єкти публічної адміністрації (горизонтальні), що розкриваються через сукупність в адміністративноправових відносинах адміністративних прав і публічних обов'язків суб'єктів публічної адміністрації.

Підставою для виникнення, зміни та припинення правовідносин у сфері адміністративно-правового забезпечення кібернетичної безпеки людини є юридичний факт. Юридичний факт - це конкретна життєва обставина, з якою норми права пов'язують виникнення, зміну чи припинення правовідносин ${ }^{15}$. У цьому контексті варто зазначити, що правовідносини у сфері адміністративно-правового забезпечення кібернетичної безпеки людини можуть виникати на таких підставах: при реалізації людиною прав, свобод та інтересів, що їй належать під час використання кібернетичного простору, а також при виконанні обов'язків у цій сфері (правомірні дії); при необхідності охорони і захисту прав, свобод та інтересів, що їй належать під час використання кібернетичного простору (правомірні діi)); при порушенні обов'язків людиною під час використання кіберпростору (неправомірні діiі).

Суб'єкти публічної адміністрації в процесі надання адміністративних послуг і здійснення виконавчорозпорядчої діяльності відповідно до своєї компетенції можуть застосовувати такий арсенал інструментів (засобів) публічного адміністрування: видання правових актів (нормативних та індивідуальних адміністративних актів); укладення адміністративних договорів; учинення інших юридично значущих дій; здійснення матеріально-технічних операцій; затвердження планів діяльності; використання методів публічного адміністрування, а саме методів заохочення; методів переконання; методів адміністративного примусу, до яких входять: а) адміністративно-запобіжні заходи; б) заходи адміністративного припинення; в) адміністративні стягнення; впровадження електронного врядування тощо ${ }^{17}$.

Адміністративно-правовому забезпеченню кібернетичної безпеки людини притаманне застосування більшості із вищеперерахованих інструментів (засобів) публічного адміністрування з боку суб'єктів, відповідальних за ії забезпечення. Особливої уваги заслуговує проблема реалізації методів заохочення та стимулювання сфери забезпечення кібернетичної безпеки людини. Так, для удосконалення механізму адміністративно-правового забезпечення кібербезпеки людини до законодавства України у перспективі могли би бути додані норми, що містили б порядок застосування засобів морального та матеріального заохочення (стимулювання) для забезпечення належного функціонування і використання кібернетичного простору. Закон України «Про основні засади забезпечення кібернетичної безпеки» окреслює можливі напрями державноприватної взаємодії у сфері кібербезпеки, однак не містить будь-яких заохочуючих (стимулюючих) норми щодо здійснення такого партнерства.

Нині зусилля суб'єктів публічної адміністрації мають бути першочергово спрямовані на стимулювання сфери кібербезпеки, з метою нарощування потенціалу цієї галузі, через використання таких засобів, як відкриття грантових програм; надання додаткового фінансування не лише органам державної влади, що здійснюють публічне адміністрування у сфері забезпечення кібернетичної безпеки, а й приватним особам, які працюють у цій сфері. Доцільно було б також застосовувати певні пільги або визначити порядок повної чи часткової компенсації освітніх послуг для осіб, які пройшли відповідне навчання з метою підвищення рівня знань у галузі кібербезпеки тощо. 


\section{Висновки.}

1. Механізмом адміністративно-правового забезпечення кібернетичної безпеки людини можна вважати узяту в єдності складну систему юридичних, організаційних, ідеологічних, технічних та інших заходів впливу, що здійснюється уповноваженими суб'єктами публічної адміністрації на суспільні відносини, які виникають під час використання кібернетичного простору, з метою їх упорядкування, а також для забезпечення охорони та захисту життєво важливих інтересів, прав та свобод людини у цій сфері.

2. До основних елементів механізму адміністративно-правового забезпечення кібернетичної безпеки людини можна віднести: нормативні засади механізму адміністративно-правового забезпечення кібернетичної безпеки людини (принципи права, норми права); об'єкт адміністративно-правового забезпечення кібернетичної безпеки людини (правовідносини, їх зміст, види, структуру та особливості реалізації); суб'єктів адміністративно-правового забезпечення кібернетичної безпеки людини; засоби адміністративно-правового забезпечення кібернетичної безпеки людини.

3. Механізму адміністративно-правового забезпечення кібернетичної безпеки людини притаманна динамічність, зважаючи на специфіку предмета правового регулювання, і тому він має максимально враховувати закономірності розвитку суспільства, науки, а також технологій для того, аби бути ефективним і здатним належним чином задовольняти, охороняти та захищати життєво важливі інтереси, права та свободи людини під час використання кібернетичного простору.

${ }^{1}$ Rolf H.Weber, Evelyne Studer. Cybersecurity in the Internet of Things: Legal aspects. URL: https://www.sciencedirect.com/sci ence/article/abs/pii/S0267364916301169

2 Ronald J. Deibert. Toward a Human-Centric Approach to Cybersecurity. URL: https://www.cambridge.org/core/journals/ethicsand-international-affairs/article/abs/toward-a-humancentric-approach-to-cybersecurity/4E8819984202A24186BB0F52E51BC1E4\# access-block

3 Заярний О.А. Правове забезпечення розвитку інформаційної сфери України: адміністративно-деліктний аспект: монографія. Київ: Видавничий дім «Гельветика». 2017. 700 c. URL: http://ippi.org.ua/sites/default/files/zayarnii monografiya tv pereplet 0.pdf

4 Золотар О.О. Правові основи інформаційної безпеки людини : автореф. дис. ... д-ра юрид. наук : 12.00.07. Харків, 2018. $39 \mathrm{c}$.

5 Омельчук В.А. Міжнародний науковий журнал «Інтернаука». Серія «Юридичні науки». Київ. 2020. № 9. С. $55-61$.

6 Тарасюк А.В. Методологічні підходи до вивчення проблеми безпеки людини в кіберпросторі. Підприємництво, господарство і право. 2020. № 7. С. 254-258.

${ }^{7}$ Olyinyk O. Akademická spoločnost' Michala Balud'anského (Košice, S. (2013). Scientific letters of Academic Society of Michal Baludansky. Košice: Academic Society of Michal Baludansky. Інформаційна безпека у зарубіжних країнах.

8 Мельник Я.Я. Місце феномену «безпеки» в цивільних процесуальних категоріях «інтерес», «свобода», «право», «обов’язок» та «відповідальність». Науковий вісник Ужгородського національного університету. 2016. № 39. С. 65-70. (Серія «Право»).

9 Definition of 'mechanism'. URL: https://www.collinsdictionary.com/dictionary/english/mechanism

10 Мартюшов В.Ф. Понятие «механизм» в контексте изучения социальных процессов. URL: http://eprints.tversu.ru/5500/1/ Вестник_ТвГУ._Серия_ФИЛОСОФИЯ._2015._3._С._94-103.pdf

11 Діденко С.В. Поняття та елементи механізму адміністративно-правового забезпечення обігу та застосування зброї в Україні. Наукові праці Національного університету «Одеська юридична академія». 2015. Т. 16. C. 463-469. C. 464. URL: http://nbuv.gov.ua/UJRN/Nponyua_2015_16_52

12 Личенко І. Поняття та ознаки адміністративно-правового забезпечення екологічної безпеки в Україні. Вісник Національного університету «Львівська політехніка»: зб. наук. праць. Львів: Вид-во Львівської політехніки, 2017. № 876. С. 163-169. С. 168 (Серія «Юридичні науки»).

13 Алексеев С.С. Механизм правового регулирования в социалистическом государстве. Москва: Юридическая литератуpa, 1966. 187 c. C. 5.

14 Сидоренко О.П. Правове забезпечення: до питання інтерпретації поняття. Актуальні проблеми вітчизняної юриспрудениіï. 2018. № 1. С. 39-46. С. 41.

15 Скакун О.Ф. Теорія держави і права: підручник. Харків: Консум, 2001. 656 с. С. 499.

16 Гумін О.М. Адміністративно-правове забезпечення: поняття та структура. Наше право. 2014. № 4. С. 46-50. С. 50.

17 Галунько В., Діхтієвський П., Кузьменко О. та ін. Адміністративне право України. Повний курс: підручник / за ред. В. Галунька, О. Правоторової. 3-є вид. Херсон : ОЛДІ-ПЛЮС, 2020. 584 с. С. 20. URL: http://sipl.com.ua/wp-content/uploads/ 2020/04/Галунько-АДМІН-ПРАВО-вид-третє-2020.pdf

18 Царенко C.I. Механізм адміністративно-правового забезпечення прикордонного режиму Державною прикордонною службою України. Науковий вісник Херсонського держсавного університету. 2015. Вип. 5(3). С. 83-86. С. 84 (Серія «Юридичні науки»).

19 Про основні засади забезпечення кібербезпеки України : Закон України від 5.10.2017 р. № 2163-VIII. Дата оновлення: 08.07.2018. URL: https://zakon.rada.gov.ua/laws/show/2163-19 (дата звернення: 31.12.2020).

20 Про захист персональних даних : Закон України від 1.06.2010 року № 2297-VI. Дата оновлення: 20.03.2020. URL: https://zakon.rada.gov.ua/laws/show/2297-17 (дата звернення: 31.12.2020).

21 Заярний О.А. Деякі напрями удосконалення способів захисту інформаційних прав фізичних осіб в умовах застосування технологій штучного інтелекту. Актуальні проблеми захисту інформаційних прав особи в умовах технологічних викликів та иифрової реальності: матеріали Міжнар. наук.-практ. конф. (м. Херсон, 17-18 вересня 2019 р.). Херсон: ВД «Гельветика», 2019. C. $94-98$. C. 97.

22 Еннан P.C. Правове регулювання відносин у мережі Інтернет. URL: http://aphd.ua/publication-173/

${ }^{23}$ X-Road. URL: https://en.wikipedia.org/wiki/X-Road 
24 Демиденко В.О. Принципи застосування органами місцевого самоврядування законодавства України у сфері кібербезпеки. Юридичний часопис Національної академії внутрішніх справ. 2018. № 1. С. 141-153. С. 143.

25 Громадяни та громадські об'єднання як суб'єкти адміністративного права. URL: https://arm.naiau.kiev.ua/books/adm pravo_zch/nm/lec6.html

\section{Резюме}

Плескач М.В. Сутність поняття та основні елементи механізму адміністративно-правового забезпечення кібернетичної безпеки людини.

У статті розкрито сутність поняття механізму адміністративно-правового забезпечення кібернетичної безпеки людини, а також представлено основні його елементи, а саме: нормативні засади (принципи права, норми права); визначено об'єкт адміністративно-правового забезпечення кібернетичної безпеки людини (правовідносини, їх зміст, види, структуру та особливості реалізації); суб'єктів адміністративно-правового забезпечення кібернетичної безпеки людини; засоби адміністративно-правового забезпечення кібернетичної безпеки людини. Крім того, автором окреслено можливі напрями вдосконалення національного механізму адміністративно-правового забезпечення кібернетичної безпеки людини.

Ключові слова: механізм адміністративно-правового забезпечення, кібернетична безпека людини.

\section{Резюме}

Плескач М.В. Сущность понятия и основные элементы механизма административно-правового обеспечения кибернетической безопасности человека.

В статье раскрыта сущность понятия механизма административно-правового обеспечения кибернетической безопасности человека, а также представлены основные его элементы, а именно: нормативные основы (принципы права, нормы права); определены объект административно-правового обеспечения кибернетической безопасности человека (правоотношения, их содержание, виды, структура и особенности реализации); субъекты административно-правового обеспечения кибернетической безопасности человека; средства административно-правового обеспечения кибернетической безопасности человека. Кроме того, автором обозначены возможные направления усовершенствования национального механизма административноправового обеспечения кибернетической безопасности человека.

Ключевые слова: механизм административно-правового обеспечения, кибернетическая безопасность человека.

\section{Summary}

\section{ments.}

Mariia Pleskach. The mechanism of administrative and legal support of human cybersecurity: concept and basic ele-

This research presents the result of the mechanism theoretical modeling of administrative and legal support of human cybersecurity.

Author attempt to determine the concept and basic elements of human cybersecurity administrative and legal support.

Such a definition of the mechanism of administrative and legal support of cyber security as a unity of a complex system of legal, organizational, ideological, technical and other measures of influence carried out by authorized subjects of public administration on public relations arising during the use of cyberspace, in order to streamline them, as well as to ensure the protection and defense of vital human interests, rights and freedoms is proposed.

Such elements as regulatory principles (principles of law, rule of law); object of administrative and legal support of human cybersecurity (legal relationships, their types, structure and features of realization); subjects of administrative and legal support of human cyber security; instrumentality of administrative and legal support of human cyber have been highlighted. security.

The author outlines possible directions for improving the national mechanism of administrative and legal support of human cyber

The mechanism of administrative and legal support of cyber security is characterized by dynamism due to the specifics of the legal regulation subject. Therefore, it should take into account the peculiarities of society, science and technology, in order to be effective and able to protect important human interests, rights and freedoms in cyberspace.

The problem of implementing methods to encourage and stimulate the sphere of human cybersecurity requires special attention.

In order to improve the mechanism of administrative and legal support of human cyber security, rules should be added to the legislation of Ukraine, which would contain the procedure for the use of moral and material incentives to ensure the functioning and use of cyberspace.

Public administration efforts should also be aimed at stimulating cybersecurity, which will help build the capacity of this sphere. They can use methods such as opening grant programs; providing additional funding to private subjects. It would also be appropriate to apply certain benefits or to determine the procedure for full or partial compensation of educational services for persons who have undergone appropriate training in order to increase the level of knowledge in the sphere of cybersecurity, etc.

Key words: mechanism of administrative and legal support, human cybersecurity. 